\title{
Sprawozdanie
}

\section{Seminarium Badaczy Prawa Konstytucyjnego \\ Bezpieczeństwo w Konstytucji RP z 1997 r., Toruń, 16-18 września 2014 r.}

Seminaria Badaczy Prawa Konstytucyjnego stanowią ciekawą inicjatywę młodego pokolenia konstytucjonalistów i politologów, służącą prezentacji wyników prowadzonych badań, wymianie poglądów i doświadczeń, a przede wszystkich integracji środowiska naukowego, która już na stałe wpisała się w kalendarz spotkań konferencyjnych.

Jubileuszowe - X Seminarium Badaczy Prawa Konstytucyjnego odbyło się w dniach 16-18 września 2014 r. w toruńskim Forcie IV. W tej niecodziennej scenerii pruskich fortyfikacji przybyli z całej Polski goście dyskutowali na temat kategorii bezpieczeństwa w Konstytucji RP z 1997 r. Gospodarzem jubileuszowego Seminarium, zorganizowanego pod patronatami honorowymi ministra obrony narodowej Tomasza Siemoniaka i prezydenta m. Torunia Michała Zaleskiego, była Katedra Prawa Konstytucyjnego Uniwersytetu Mikołaja Kopernika w Toruniu. Kierownikiem naukowym i głównym organizatorem tego przedsięwzięcia była p. dr hab. Agnieszka Bień-Kacała.

Program seminarium obejmował prezentację dziesięciu wystąpień w czterech sesjach tematycznych dotyczących zarówno ogólnej problematyki bezpieczeństwa, jak też szczegółowych kategorii bezpieczeństwa w Konstytucji RP. Uroczystego otwarcia konferencji dokonali Wicemarszałek Senatu RP - Jan Wyrowiński, przedstawiciel prezydenta m. Torunia - p. dyr. 
Romuald Popławski, przedstawiciel Dziekana Wydz. Prawa i Administracji UMK - dr Mikołaj Święcki oraz prof. dr hab. Zbigniew Witkowski. Adres posła do Parlamentu Europejskiego, b. wiceministra obrony Janusza Zemke przedstawił zgromadzonym jego przedstawiciel dr Tomasz Kruszyński. Toruńskie Seminarium swoją obecnością uświetnili również dr Adam Marszałek - prezes Marszałek Publishing Group oraz dr hab. Joanna Marszałek-Kawa - prezes Wydawnictwa Adam Marszałek.

Pierwszą sesję, której przewodniczył prof. dr hab. Zbigniew Witkowski z Uniwersytetu Mikołaja Kopernika w Toruniu, zainaugurował referat dr hab. Agnieszki Bień-Kacały zatytułowany „Bezpieczeństwo w świetle regulacji konstytucyjnej - wstępna diagnoza”. Dokonana przez referentkę analiza regulacji konstytucyjnej dowodzi, że termin „bezpieczeństwo” pojawia się kilkakrotnie w przepisach ustawy zasadniczej. Warto zwrócić jednak uwagę, że zawsze termin ten powiązany jest $\mathrm{z}$ dookreśleniem rodzaju bezpieczeństwa. Mamy więc do czynienia $z$ bezpieczeństwem postrzeganym podmiotowo: obywateli, państwa, konsumentów, użytkowników i najemców oraz przedmiotowo: wewnętrznym, zewnętrznym, ekologicznym oraz z bezpiecznymi warunkami pracy. W podsumowaniu swojego wystąpienia prof. A. Bień-Kacała postulowała sformułowanie na gruncie prawa konstytucyjnego kategorii bezpieczeństwa Rzeczypospolitej Polskiej uwzględniającej trzy elementy: bezpieczeństwo państwa, bezpieczeństwo obywateli oraz dobro wspólne jako kategorię relewantną w tworzeniu nowego podejścia do bezpieczeństwa.

Następnie głos zabrał dr Wojciech Włoch z Uniwersytetu Mikołaja Kopernika w Toruniu, który zaprezentował zagadnienie relacji wolności i bezpieczeństwa w myśli T. Hobbesa i J. Locke’a. Pierwsza z analizowanych teorii opiera się na założeniu o konieczności istnienia „ośrodka decyzyjnego” zapewniającego „zbiorowe bezpieczeństwo” (prymat bezpieczeństwa), w drugiej podkreśla się z kolei, że władzę polityczną ograniczają podstawowe wolności jednostki (prymat praw jednostki). Zdaniem referenta krytyczna analiza przedstawionych modeli dowodzi, że współcześnie nie można interpretować konieczności istnienia władzy politycznej czy też zapewnienia gwarancji praw jednostki w sposób absolutystyczny.

W drugiej sesji, której przewodniczyła prof. dr hab. Sabina Grabowska z Uniwersytetu Rzeszowskiego, uczestnicy seminarium wysłuchali czterech referatów. Problematykę zwierzchnictwa prezydenta nad Siłami Zbrojnymi 
RP w czasie wojny przybliżył mgr Michał Szewczyk, doktorant w Katedrze Prawa Konstytucyjnego UMK w Toruniu. Analizując normatywne podstawy sprawowania przez głowę państwa funkcji najwyższego zwierzchnika Sił Zbrojnych RP w czasie wojny, referent podkreślił, że od strony formalnej ulega ono zasadniczemu wzmocnieniu względem czasu pokoju. W ocenie mgr M. Szewczyka efektywne sprawowanie zwierzchnictwa nad Siłami Zbrojnymi w czasie wojny może okazać się trudne. Wynika to przede wszystkim z zasadniczej słabości wielu regulacji prawnych dotyczących czasu wojny związanych m.in. z brakiem przepisów prawnych traktujących o funkcjonowaniu państwa w czasie wojny, w tym kierowaniu jego obroną.

O roli Rady Bezpieczeństwa Narodowego jako konstytucyjnego organu doradczego prezydenta RP w zakresie bezpieczeństwa wewnętrznego i zewnętrznego państwa traktowała w swoim wystąpieniu dr Joanna Juchniewicz z Uniwersytetu Warmińsko-Mazurskiego w Olsztynie. Zdaniem Autorki referatu realna ocena działalności Rady Bezpieczeństwa Narodowego wymyka się jednoznacznym ocenom. Wynika to w dużej mierze $\mathrm{z}$ faktu, iż jest to organ pozbawiony jakichkolwiek uprawnień władczych, a przez to uznawany przez niektórych polityków za organ fasadowy. Faktyczna jej rola determinowana jest natomiast sposobem sprawowania prezydentury i zaangażowaniem głowy państwa w sprawy związane z bezpieczeństwem państwa polskiego.

Jako następny głos zabrał ppłk dr Tomasz Kacała z Centrum Doktryn i Szkolenia Sił Zbrojnych w Bydgoszczy. W referacie zatytułowanym „Dezinformacja i propaganda w kontekście zagrożeń dla bezpieczeństwa państwa" na licznych przykładach dowodził, że zarówno informacja, jak i propaganda nie są celem samym w sobie. Są one środkiem do osiągnięcia określonego, $\mathrm{z}$ reguły długofalowego celu politycznego lub wojskowego, zaś ich rozwój ściśle związany jest z postępem techniki komunikowania społecznego.

Ostatni referat w sesji przedpołudniowej wygłosił dr Marcin Dąbrowski z Uniwersytetu Warmińsko-Mazurskiego w Olsztynie. Analizując problem dopuszczalności zmiany ustawodawstwa polskiego w kierunku legalizacji możliwości zastosowania nadzwyczajnych technik przesłuchań osób fizycznych z użyciem lub groźbą użycia przemocy fizycznej lub psychicznej w celu uzyskania informacji zmierzających do likwidacji stanu zagrożenia sprowadzonego przez terrorystów w sytuacji ziszczenia się przesłanek tzw. scenariusza tykającej bomby, referent dowodził, że o ile teoretycznie w świetle postanowień obowią- 
zującej Konstytucji RP możliwe byłoby uchwalenie ustawy ograniczającej zakaz stosowania tortur $\mathrm{w}$ analizowanym przypadku, o tyle taki akt zawsze sprzeczny byłby z postanowieniami prawa międzynarodowego i europejskiego. Jak argumentował bowiem dr M. Dąbrowski, wiążące Rzeczpospolitą umowy międzynarodowe zobowiązują państwo polskie do bezwzględnego przestrzegania zakazu stosowania tortur i nie zawierają postanowień, które umożliwiałyby wyłączenie lub ograniczenie bezwzględnego charakteru tej klauzuli.

W czasie trzeciej sesji, której przewodniczyła dr Joanna Juchniewicz, przedstawiono dwa wystąpienia. Jako pierwsza głos zabrała dr Anna Rytel-Warzocha z Uniwersytetu Gdańskiego, która przedstawiła referat pt. „Bezpieczeństwo państwa a konstytucyjnie chronione prawa i wolności jednostki”. Poddając obszernej analizie orzecznictwo Trybunału Konstytucyjnego, Autorka referatu dowodziła, że kwestia ograniczeń wolności i praw jednostki dotyka jednego z najtrudniejszych zagadnień konstytucyjnych, jakie może stanąć przed organami stanowiącymi i stosującymi prawo.

O bezpieczeństwie i porządku publicznym jako przesłankach ograniczenia prawa do sądu traktowali w swoim wystąpieniu dr Marta Kłopocka-Jasińska z Wyższej Szkoły Prawa im. Heleny Chodkowskiej we Wrocławiu i dr Wojciech Jasiński z Uniwersytetu Wrocławskiego. Jak wskazywali referenci, zdarzyć się może sytuacja, w której dojdzie do kolizji prawa do sądu z inną normą konstytucyjną, poddającą pod ochronę wartości o równym lub nawet większym znaczeniu dla funkcjonowania państwa lub rozwoju jednostki. Konieczność uwzględnienia obu norm konstytucyjnych może zatem przemawiać za wprowadzeniem pewnych ograniczeń zakresu przedmiotowego prawa do sądu, o ile urzeczywistnienie danej wartości konstytucyjnej nie jest możliwe w inny sposób.

W ostatniej, czwartej sesji jubileuszowego Seminarium Badaczy Prawa Konstytucyjnego, której przewodniczył dr Jerzy Rychlik (Instytut Nauk Prawnych PAN), zaprezentowano dwa wystąpienia. Jako pierwsza swój referat przedstawiła dr Agnieszka Gajda z Uniwersytetu Gdańskiego. Referentka zwróciła uwagę, że kwestie potencjalnego zagrożenia bezpieczeństwa stanowią ważną przesłankę ograniczania konstytucyjnej wolności zgromadzeń publicznych. Niepokojący jest jednak pewien automatyzm wydawanych zakazów. W podejmowanych decyzjach często brakuje bowiem przekonującego uzasadnienia, które wskazywałoby na rzeczywistą niemożność przeprowadzenia zgromadzenia ze względu na istnienie realnego zagroże- 
nia bezpieczeństwa lub porządku publicznego. Zdaniem dr A. Gajdy praktyka organów władzy publicznej w tym względzie daleka jest od ideału i może prowadzić do podważenia zasady zaufania obywatela do państwa.

Toruńskie seminarium zwieńczył referat dr Anny Frankiewicz z Uniwersytetu Opolskiego poświęcony kwestii bezpieczeństwa dóbr kultury. Omawiając regulacje prawne dotyczące dziedzictwa, kultury, dóbr kultury oraz ich ochrony, referentka podkreśliła, że prawo do dziedzictwa to jedno z niezbywalnych praw człowieka i wyraz suwerenności kulturalnej narodu. To kultura daje bowiem człowiekowi poczucie pewności wynikające ze wspólnej przeszłości i planowanej przyszłości, a także nadaje autentyczny sens zaangażowaniu obywatelskiemu.

Wygłoszone referaty stały się przyczynkiem do burzliwej dyskusji, zwłaszcza w kontekście problemu zwierzchnictwa nad Siłami Zbrojnymi RP w czasie wojny czy dopuszczalności stosowania tortur w walce $\mathrm{z}$ terroryzmem. Głos w dyskusji zabrali m.in. prof. Z. Witkowski, dr W. Jasiński, dr M. Wiszowaty, dr R. Balicki, prof. nadzw. dr hab. A. Ławniczak, dr K. Urbaniak oraz dr K. Składowski. W chwili wytchnienia od obowiązków konferencyjnych uczestnicy Seminarium mieli możliwość spróbowania swoich sił w turnieju strzeleckim oraz aktywnie uczestniczyli w pokazowej demonstracji ratownictwa medycznego.

Organizatorzy X Seminarium Badaczy Prawa Konstytucyjnego pragną szczególnie podziękować władzom Grodu Kopernika na czele z prezydentem m. Torunia M. Zaleskim za osobistą życzliwość i wsparcie, na jakie Katedra Prawa Konstytucyjnego WPiA UMK w Toruniu mogła zawsze liczyć przy organizacji przedsięwzięć naukowych. Organizując rozmaite zjazdy, kolokwia i seminaria naukowe, zwłaszcza te o wymiarze międzynarodowym i ogólnopolskim, także Katedra Prawa Konstytucyjnego akcentuje swoje przywiązanie do niezwykłego miasta, jakim jest Toruń. Przykładem tego jest choćby polsko-włoski periodyk "Studi polacco-italiani di Toruń, mający akcent „toruński” w swojej nazwie. Stałym elementem programów kulturalnych towarzyszących naszym przedsięwzięciom naukowym stało się również prezentowanie uroków gotyckiego Torunia albo jego szczególnie ciekawych zabytków, jakim tym razem był Fort IV.

Maciej Serowaniec Uniwersytet Mikołaja Kopernika w Toruniu 